\title{
Public Relations in the College Library
}

\author{
BY L. A. KENNEY
}

THE PROMOTION of good public relations is of utmost importance to the successful accomplishment of high quality library service - the goal of every academic library. Yet too often public relations is left to chance or is ignored altogether. College librarians should do a better promotional job than they have done in the past, if they hope to get and keep administration, faculty, and community support for the kind of library service demanded by today's students and research scholars.

Too many college and university librarians think public relations programs are for public libraries. They believe, perhaps, that public relations is some sort of advertising employed by public libraries to get people to come to the library or to increase circulation statistics, while on the campus the faculty propels students into the library, and the college librarian does not have to waste time on advertising.

Good public relations is more than mere advertising, and it is never accidental. It is the result of well-thought-out and coordinated efforts. No doubt nearly all librarians are in favor of better public relations. Who isn't? But how do we inaugurate a good public relations program? There are, fortunately, guidelines to follow.

Public relations is the personal contact in all activities of an institution intended to influence the attitudes and opinions of the library staff, the administration of the college, the faculty, the students, and the community. Its chief ingredient is good human relations.

\author{
Dr. Kenney is Librarian in San Diego \\ State College.
}

Public relations is usually thought by librarians to mean preparing occasional news releases, lists of new books added to the library, handbooks on how to use the library, and similar publicity items. But preparing releases, and handing out brochures and lists of new acquisitions are only aspects of a public relations program.

Good public relations involves the whole staff and everything it does. On the staff where good public relations exists there is a spirit of good will and enthusiasm. It pervades the whole library atmosphere. Good public relations calls for the cultivation and practice of good human relations.

How does the librarian go about the development of good human relations? There are no easy answers. It is something like leadership in that it is hard to define. But something can be done to develop better understanding of human relations. Surely there is nothing more challenging than to learn more about the art of getting along well with fellow human beings. There is a need for librarians to be friendly. Attitudes, conscious and unconscious, toward fellow human beings call for scrutiny.

The college librarian may begin building a good public relations program by recognizing four distinct "publics," named here in order of importance: (1) the library staff, (2) the library's superior officer in the college administration, (3) the faculty, and (4) the student body. 
The establishment and maintenance of good public relations with the library's first "public," the library staff, is the sine qua non of all college library public relations. If the librarian does not succeed here, there can be no satisfactory library public relations program with the other "publics."

The promotion of good public relations with the library staff presumes above all good administration. It calls for fair personnel practices and democratic processes. Library policies and activities must be carried on in consultation with the staff. Democratic forms may seem cumbersome and time-consuming, but they should be introduced and practiced. The high morale growing out of good administrative practices will pay off rich dividends.

In building good human relations on the staff, the library administrator must include the staff in the planning and the decision-making process. Library supervisors may not play favorites, and they cannot run their departments as one-man shows. The chief librarian and the supervisors must take the staff into their confidence. The whole staff must be kept informed of library affairs, policies, decisions, new regulations, promotions, vacation plans, and similar matters. A poorly informed staff dreams up and spreads fantastic morale-killing rumors that will cancel out the best efforts to create good will.

Library supervisors, including the head librarian, must always be ready to listen to their staff members. This suggests that they should be available even without the formality of making appointments in advance through a secretary. The head librarian today treats his supervisors, and indeed, the whole staff, as colleagues and friends. $\mathrm{He}$ is grateful to them and tells them so. He gives genuine praise, often, but not empty flattery. Genuine praise when justly deserved accomplishes much.

Other means of building good public relations on the staff include such things as a staff organization and the publication of an informal staff news bulletin prepared by the staff, not by the library administration. A staff publication issued by the librarian's office will not be as effective as one written and published by the staff itself. The staff news bulletin should be about the library and the staff. It should have both professional and social news. It ought to be of interest to the whole staff.

In communicating with the staff, personal contact or telephone is better than written communication. When letters and memos are addressed to the staff much care should be taken to build good will. Words must be chosen with care. Brevity is important, because long memos may not be read at all, so that their messages do not get across.

It is elementary, but in all written communications negative words ought to be avoided. Think twice before using such words as: no, not, failed, failure, regret, sorry, neglected, claim, inconvenience, misled, misrepresented, complain, unreasonable, unfair, and other similar emotionally-packed words. Memos that get desired results are written in an easy and natural style. Letters and memoranda are written to express, not to impress.

If the library is to have any public relations program then, it all has to start within the staff. It calls for good administration and above all good human relations among all levels of the staff: the administration, supervisors, professional and clerical staff members, and the student assistants. Student assistants are just as important as any other staff members in building the public relations of the library.

The second most important "public" with which the librarian must promote good public relations is the administration of the institution. Generally speaking this "public" is headed by the academic dean and includes the president, comptroller, dean of students, purchasing officer, personnel manager, and others.

The librarian uses whatever human re- 
lations talent he can muster to establish and maintain a friendly relationship with the dean. The librarian should discover what the dean's real feelings are about the role of the library in the instructional program. He should listen to the dean more and talk less. The librarian should consult with him only about important matters, keeping the trivia in the library. If there is one thing a dean dislikes, it is to be brought in on all the personality clashes of the library staff.

Submission of a monthly report on the library to the dean is an invaluable public relations device. Deans do not usually ask librarians for monthly reports, but purely for public relations reasons they may be prepared. Good reports often work wonders. Indeed, there is no better way of informing the dean of library statistics and providing him with a reliable picture of library activities.

The monthly report to the dean, copies of which are circulated to library department heads and to the chairman of the faculty library committee, states how many books were circulated last month. It compares current circulation with that of the previous year. It tells how many reference questions were answered, and a sample of reference questions asked is always appended. Sample reference questions impress administrators a great deal. Most college administrators and many faculty members sincerely wonder just what reference librarians do. Twenty sample reference questions with the monthly report to the dean tell him more than several paragraphs.

The monthly report gives technical services data, too. It tells how many titles were cataloged, how many volumes were added, and it gives the current status of the book budget. Important new acquisitions are listed.

It is surprising how much the accumulated effect of the monthly report to the dean will help the library. An increased understanding of, and sympathy for, library problems on the part of the college administration will develop. When the disgruntled faculty member goes to the dean to complain about the librarians who are not doing anything but standing around the card catalog gossiping, the dean will have factual information to fall back on. He will be a more enthusiastic supporter of the library, and the librarian can feel confident that relations between the library and the college administration are not being neglected.

The third of the four "publics" with which the library must promote good public relations is the faculty. The faculty can make or break the college library, and it should never be underestimated. If librarians do not love scholars with all their foibles and idiosyncracies, they should learn to, or get out of the academic library business. The librarian should not, however, go so far as to team up with the faculty against the college administration. That leads to disaster, too.

If good relations exist within the library staff, more than half the problem of good relations with the faculty will already be accomplished. Staff members who are happy with their work and proud of their library will seldom complain and will cheerfully serve faculty members.

In dealing with the faculty, the entire library staff should adhere to the old public relations principle that rules and regulations were made to be bent but not broken. There are always people on library staffs who dislike bending the rules. It requires them to use judgment and to take responsibility. They prefer to say a rule is a rule and there are no exceptions. Such librarians cause the public relations promoters serious concern, but they can learn to bend rules for faculty members diplomatically, and they need not conclude therefore that the rules are worthless.

Written communication with the faculty is extremely important. Correct titles, form of address, grammar, spelling and typography in communications are im- 
portant to those exacting people. Words must be chosen most carefully. Extreme tact should be employed in even routine correspondence.

A college library should issue some kind of publication tailored specifically to faculty needs, even if it is only a monthly or quarterly selected list of new titles added to the library. The format of the list of new titles sent to the faculty is important. Some libraries put out lists of new books acquired by the library that look like factory inventory lists of nuts and bolts. There is no masthead on some college library publications; other do not carry the name of the library. These publications show no hint of any public relations consciousness. It takes only an insignificant amount of thought and time to dress up publications so that they are intelligent and appealing to the eye. College libraries would get much more public relations value with a little more effort.

The faculty library committee is of considerable value in promoting good public relations. The librarian should not be concerned with what matters the committee takes up. The committee's advice should be respected. The librarian should take care not to do much talking at committee meetings. He should rather be available for factual information on library matters when committee members call upon him.

Finally there is the library's fourth "public," the students. They are the people for whom the library and the whole institution exist. Building public relations with them will be easier if relations within the library staff and with administration and faculty are good.

The most important aspect of public relations with students is the direct personal contact between the library staff member and the individual student at the service desk. The chief librarian must see that public services librarians are warm, sympathetic, and approachable persons. It is all too common, perhaps, to find librarians who took up librarianship be- cause they love books, but hate people. Librarians of this kind ought not to do reference work.

In building good public relations with the students these things would help:

1. Establishment of a student committee on the library.

2 . Reasonable library rules and regulations appropriate to the most efficient use of library resources by the students. Rules should not rest on the whims or convenience of the librarians.

3. A library handbook for students prepared and distributed widely. It should be brief and clear and free of library jargon. (Who knows what a shelflist or a transaction card is?)

4. Library orientation lectures are valuable. Librarians who speak well should conduct orientation lectures and tours of the library.

5. Speeding new books to the shelves promptly promotes good public relations.

6. Suggestion boxes in the library with answers by staff members posted on a bulletin board.

7. In the matter of collecting fines and demanding payment for lost books, care should be taken not to charge when there is doubt concerning the borrower's delinquency. Charging a fine or collecting for a lost book when the borrower is not guilty may make an undying enemy of the library. It might be suspected that some of those letters to the editor published in the campus newspaper complaining about the library were inspired by student victims of errors in the circulation system whereby they were forced to pay a fine they did not deserve.

In summary, a college public relations program should be directed toward the library's four "publics" in the academic community. A publication aimed at informing each of these "publics" is recommended. In an academic community where public relations are handled skillfully the librarians are known as friendly, helpful people who use books and knowledge with competence. 